\title{
EFFECT OF PELLETING AGENT ON MICROBIOLOGICAL AND MYCOTOXICOLOGICAL SAFETY OF FEED MIXTURES
}

\author{
M. Adamović ${ }^{1}$, A. Bočarov-Stančić ${ }^{2}$, V. Pantić ${ }^{2}$, M. Vukić-Vranješ ${ }^{3}$, R. \\ Jovanović ${ }^{3}$, M. Panić ${ }^{4}$ \\ ${ }^{1}$ Institute for Technology of Nuclear and Other Mineral Raw Materials, Franše d' Eperea 86, 11000 \\ Belgrade, Republic of Serbia \\ ${ }^{2}$ Center for Bio-Ecology, d.o.o, P. Drapšina 15, 23000 Zrenjanin, Republic of Serbia \\ ${ }^{3}$ Institute for Application of Science in Agriculture, Bulavar Despota Stefana 68 b, 11000 Belgrade \\ Republic of Serbia \\ ${ }^{4}$ FSH Komponenta, Ćuprija, Cara Lazara bb, Republic of Serbia \\ Corresponding author: m.adamovic@itnms.ac.rs \\ Original scientific paper
}

Abstract: The study was conducted to determine effect of pelleting agents on physical and chemical characteristics as well as microbiological and mycotoxicological safety of pelleted feed mixtures for laying hens. Four feed mixtures were analyzed: Control $(\mathrm{K})$ - without supplemented pelleting agent, and three experimental ones (A, B and $\mathrm{C}$ ) with supplemented pelleting agent. Lignocellulose concentrate-based agent was added in feed mixture A -"Arbocel" $(2 \%)$, and bentonite-based agent in feed mixture B "Bentopel" $(2 \%)$, while both agents were added in feed mixture $\mathrm{C}$ in the concentration of $1 \%$. The pellets of highest hardness $(6 \mathrm{Khal} \mathrm{J} / \mathrm{kg})$ were found in feed mixture B. The pellets of rather good hardness $(5.5 \mathrm{Khal} \mathrm{J} / \mathrm{kg})$ were found in feed mixture A, while the pellets in feed mixture C $(3.5 \mathrm{Khal} \mathrm{J} / \mathrm{kg})$ were of the lowest hardness. Total number of bacteria was the highest in diet $\mathrm{K}$ amounting to $39000 / \mathrm{g}$ sample, and significantly lower in the experimental feeds mixtures ranging from 2,100 (C) to 5,000 (B). Pathogenic bacteria were not detected in the analyzed feeds mixtures. The highest number of yeast species (8) was found in feed mixture K, and in experimental feeds mixtures this number was significantly lower. In feed mixture A one yeast species was found, in feed mixture B three and in feed mixture C 6, respectively. The predominant were the representatives of the Aspergillus species, a typical mycobiota developed in the animal feed warehouses. Presence of mycotoxins (aflatoxin B1, ochratoxin A, zearalenone, deoxynivalenol, diacetoxyscirpenol and $\mathrm{T}-2$ toxin) was not detected in analyzed feeds mixture. pelleting

Key words: feed mixtures, microbiological and mycotoxicological safety, 


\section{Introduction}

Safe food production is an imperative for the global food and feed production. Technological and technical processes which contribute to the reduction of food contamination are, therefore, gaining particular importance. Feed mixture pelleting is one of such processes. Pelleting process involves forcing ground feed mixture through die openings under pressure, with or without steam addition, to form the pellet. Under the influence of steam and friction, temperature is increased up to $70-80{ }^{\circ} \mathrm{C}$. The resulting partial degradation of carbohydrates leads to improved digestibility (of starch, hemicellulose, cellulose and pentozane), enhanced metabolic energy, increased palatability and feed mixture consumption and, finally, helps promote chewing and saliva production. In addition, pelleting enables better utilization of finely ground feed mixtures and increases volume weight of pelleted feed mixture. Pelleted feed is less susceptible to spoiling, moisture and odour adsorption, decomposition and transportation losses. Heat generated during pelleting operation, reduces total microbial count (Chukwuka et al., 2010; Lević and Sredanović, 2010; Đorđević and Dinić, 2007; Sretenović et al., 1995). And finally, pelleting process induces degradation of thermolabile antinutrients and undesirable feed mixtures ingredients (trypsin inhibitor, lectin, urease, peroxidase, lipoxygenase, myrosinase, glucosinolate, gossypol and others). Overall result is better productivity, health performance and economic benefits (Grubić, 1995; Stojanović et al., 2008). Following is used to improve pellet quality (hardness): molasses, calcium-lignosulfonate, sodium or calcium-bentonite, lignocellulose concentrate, and other organic or inorganic supplements (Withlow and Hagler, 2009). However, lignocellulose concentrate-based or bentonite-based pelleting agents are the most interesting due to their functional properties.

Lignocellulose concentrate is obtained by fibrillation process and comprises fibrillated, cellulose-containing fibers which stimulates growth of intestinal villi and significantly reduce mucosal damage in young, growing animals. Furthermore, it develops a network in himus that facilitates enzyme and nutrient movement, improves digestion, and accelerates passage and excretion of bacteria and bacterial toxins from the gut. It contains no mycotoxins, as opposed to wheat bran and other plant by-products.

Bentonite is a hydrated aluminium silicate of the volcanic origin containing montmorillonite minerals (50-90\%). Its chemical composition varies dependent on the conditions under which a bentonite deposit had formed, but commonly it contains 46-58 \% $\mathrm{SiO}_{2} ; 12-22 \% \mathrm{Al}_{2} \mathrm{O}_{3} ; 0.20-0.40 \% \mathrm{~K}_{2} \mathrm{O} ; 0.04-0.08 \% \mathrm{Na}_{2} \mathrm{O} ; 1.70-$ $3.50 \% \mathrm{MgO} ; 3.30-5.90 \%, \mathrm{CaO} ; 3.50-4.70 \% \mathrm{Fe}_{2} \mathrm{O}_{3}$. It is found to produce good results in animal feed pelleting processes thanks to its water absorption and swelling properties. Bentonite has good swelling capacity and bonding power (water and oil). Layers in its crystal structure, i.e. a layer lattice are about $1 \mathrm{~nm}$ 
thick, and separation between the layers is admitted in the presence of water molecules, thus allowing ingress of water between the layers. Separation between the layers amounts to $0.9-2.1 \mathrm{~nm}$. Bentonite absorbs water up to 1.5 times its own mass and 1.2 times its own volume Its cation exchange capacity - CEC is $80-120$ $\mathrm{meq} / 100 \mathrm{~g}$. Bentonite gives a large surface area in proportion to the volume used, $1 \mathrm{~g}$ of bentonite covers the surface of $700-800 \mathrm{~m}^{2}$. Due to its amphoteric properties (absorbs and releases hydrogen ions) it is also used to maintain the rumen $\mathrm{pH}$ in ruminants and compensate adverse effect of the ruminal $\mathrm{pH}$ depression on milk fat content. Bentonite binds aflatoxins $\left(B_{1}, B_{2}, G_{1}\right.$ and $\left.G_{2}\right)$ in feed and reduces aflatoxin $\mathrm{M}_{1}$ residues in milk (from 60 to $90 \%$ ). Its capacity to absorb zearalenone and ochratoxin is limited. Bentonite supplemented dairy cow rations have proved effective in reducing milk contamination with ${ }^{137} \mathrm{Cs}$ and ${ }^{134} \mathrm{Cs}$ by $50 \%$ to $80 \%$. Bentonite absorbs excessive $\mathrm{NH}_{3}$ from rumen when its concentration is high, that is, releases it when $\mathrm{NH}_{3}$ concentration in rumen is low, thus providing for more efficient nitrogen utilization from ammonia for microbial protein synthesis. Consequently, the resorption of $\mathrm{NH}_{3}$ in blood, liver load and energy consumption for urea synthesis is decreased. Bentonite capacity to bind water and swell contributes to enlarged digesta volume in the gut, and, resultingly, to reducing its passage through the intestinal tract, thus allowing for prolonged enzymatic action and enhanced digestibility of nutrients (Pasha et al., 2008). Bentonite may also decrease $\mathrm{Cu}, \mathrm{Zn}$ and $\mathrm{Mg}$ solubility in rumen and adsorption capacity of some minerals, giving rise to concern in the case of diets containing suboptimal levels of these minerals and vitamins (Adamović et al., 2009). Thanking to its ability to decrease $\mathrm{Cu}$ solubility in rumen, bentonite may be useful in treating chronic $\mathrm{Cu}$ intoxication in animals. Besides improved pellet hardness, yet another advantage of bentonite application in feed pelleting is reduced wear and tear of pelletizer due to excellent free flowing properties of the pellets while passing through the die openings.

The objective of the study was to determine effect of lignocellulose concentrate-based and bentonite-based pelleting agents on physical and chemical characteristics as well as microbiological and mycotoxicological safety of pelleted compound feed for laying hens.

\section{Materials and Methods}

Feed mixtures for laying hens was manufactured by the feedmill Komponenta Ćuprija. Feed mixtures was made in the counter-current horizontal mixer (Buhler), capacity 3,000 kg. Pelleting was performed at the pellet machine of the same manufacturer. Pellets were $4 \mathrm{~mm}$ in diameter and $4.6 \mathrm{~mm}$ long. Composition of used feed mixtures is given in Table 1. 
Control feed mixture $(\mathrm{K})$ was without pelleting agent, and three experimental feed mixtures (A, B and $\mathrm{C}$ ) with supplemented pelleting agent. Lignocellulose concentrate-based agent was added in feed mixture A $(2 \%)$, bentonite-based agent in feed mixture B $(2 \%)$, while both agents were added in feed mixture $\mathrm{t} C$ in the concentration of $1 \%$.

Lignocellulose concentrate was manufactured by JRS Germany (trade name "Arbocel"). Agent based on natural bentonite clay was produced in the Institute for Technology of Nuclear and Other Mineral raw Materials in Belgrade (trade name "Bentopel").

Samples for laboratory analyses were stored in plastic bags, $20 \mathrm{~cm}$ above the floor, in a dark, dry and ventilated room. Average temperature in the sample storage room was maintained at $18{ }^{\circ} \mathrm{C}$. Following 20 days of storage samples were analyzed for physical, chemical, microbiological and mycotoxicological properties.

Chemical analyses included chemical composition and trace elements of major concern. These analyses were conducted with standard laboratory methods and procedures in the accredited laboratories Eko-Lab, do.o. in Padinska Skela and the Institute for Technology of Nuclear and Other Mineral raw Materials in Belgrade. Pellet hardness was determined in the Institute of Food Technologies in Novi Sad according to Thomas and Poel (1996) methods and ASAE S269.4/1996.

Table 1. Composition of feed mixtures (\%)

\begin{tabular}{|l|c|c|c|c|}
\hline Components & $\mathrm{K}$ & $\mathrm{A}$ & $\mathrm{B}$ & $\mathrm{C}$ \\
\hline Corn & 45.9 & 45.9 & 45.9 & 45.9 \\
\hline Soybean meal & 12.5 & 12.5 & 12.5 & 12.5 \\
\hline Soya grits & 6.0 & 6.0 & 6.0 & 6.0 \\
\hline Sunflower meal & 9.3 & 9.3 & 9.3 & 9.3 \\
\hline Soya cake & 5.0 & 5.0 & 5.0 & 5.0 \\
\hline Yeast & 1.5 & 1.5 & 1.5 & 1.5 \\
\hline Corn meal & 6.0 & 4.0 & 4.0 & 4.0 \\
\hline Soya oil & 1.5 & 1.5 & 1.5 & 1.5 \\
\hline Limestone & 9.8 & 9.8 & 9.8 & 9.8 \\
\hline Mono-calcium phosphate & 1.0 & 1.0 & 1.0 & 1.0 \\
\hline Sodium bicarbonate & 0.1 & 0.1 & 0.1 & 0.1 \\
\hline Sodium chloride & 0.2 & 0.2 & 0.2 & 0.2 \\
\hline Vitamin \& Trace element premix & 1.0 & 1.0 & 1.0 & 1.0 \\
\hline Methionine & 0.1 & 0.1 & 0.1 & 0.1 \\
\hline Lysine & 0.1 & 0.1 & 0.1 & 0.1 \\
\hline "Arbocel” & 0 & 2.0 & 0 & 1.0 \\
\hline "Bentopel” & 0 & 0 & 2.0 & 1.0 \\
\hline Total & 100 & 100 & 100 & 100 \\
\hline
\end{tabular}

Microbiological and mycotoxicological analyses were carried out in the laboratory of Bio-Ecological Centre d.o.o. Zrenjanin, in accordance with the provisions of the Rules on Animal Feed Quality (Official Gazette no. 4/2010). For 
fungi isolation and identification Chapek agar was used with 3\% sacharose and potato dextrose agar with $2 \%$ glucose. Determination of the fungi type was carried out according to Ellis (1971), Domsh et al. (1980) and Samson and van ReenenHoekstra (1988). Presence of aflatoxin B1 (AFL B1), ochratoxin (OTA) and zearalenone (ZEA) was determined according to the Rules on the methods of sampling and carrying out physical, chemical and micro-biological analyses of animal feed, Official Gazette of SFR of Yugoslavia no. 15/1987). Type A trichothecenes (diacetoxyscirpenol - DAS and T-2 toxin) and Type B trichothecenes (deoxynivalenol - DON) were determined according to the method described by Pepeljnjak and Babić (1991).

\section{Results and Discussion}

Physical and chemical characteristics of feed mixtures. Important physical and chemical characteristics of feed mixture are given in Table 2. The pellets of highest hardness $(6 \mathrm{Khal} \mathrm{J} / \mathrm{kg}$ ) were found in feed mixture $\mathrm{B}$ with „Bentopel“ supplementation. The pellets of rather good hardness $(5.5 \mathrm{Khal} \mathrm{J} / \mathrm{kg})$ were found in feed mixture A with ,Arbocel" supplementation, while the pellets in feed mixtures $\mathrm{K}(3.7 \mathrm{Khal} \mathrm{J} / \mathrm{kg})$ and $\mathrm{C}(3.5 \mathrm{Khal} \mathrm{J} / \mathrm{kg})$ were of poorer quality.

Chemical composition of analyzed feed mixtures did not differ significantly. Feed mixtures $\mathrm{B}$ and $\mathrm{C}$ showed higher concentration of $\mathrm{Si}$ and $\mathrm{Al}$ as the result of "Bentopel" supplementation, $2 \%(\mathrm{~B})$ and $1 \%(\mathrm{C})$, respectively.

Table 2. Physical and chemical characteristics of feed mixtures

\begin{tabular}{|l|c|c|c|c|}
\hline Parameter & K & A & B & C \\
\hline Pellet hardness (Khal J/kg) & 3.7 & 5.5 & 6.0 & 3.5 \\
\hline Moisture,\% & 9.59 & 9.99 & 9.37 & 9.12 \\
\hline Crude protein ,\% & 17.78 & 17.62 & 17.56 & 17.60 \\
\hline Crude fat,\% $\%$ \% $\%$ & 5.32 & 5.27 & 5.20 & 5.24 \\
\hline Crude fiber \% & 4.55 & 5.26 & 4.35 & 4.82 \\
\hline Crude ash \% & 10.07 & 8.10 & 10.72 & 10.09 \\
\hline Ca,\% & 6.00 & 5.75 & 5.00 & 6.00 \\
\hline $\mathrm{P}, \%$ & 0.587 & 0.679 & 0.648 & 0.43 \\
\hline $\mathrm{Si}, \%$ & 0.11 & 0.12 & 1.12 & 0.56 \\
\hline $\mathrm{Al}, \%$ & 0.025 & 0.0155 & 0.210 & 0.121 \\
\hline
\end{tabular}

Bacteriological and mycotoxicological safety of feed mixtures. The highest total bacteria counts (Table 3) were found in feed mixture $\mathrm{K}(39.000 / \mathrm{g})$, while in experimental feed mixtures (A,B,C) total bacteria ranged from 2,100 to 5,000. Pathogenic bacteria (Proteus spp., Esherishia coli, coagulase positive Staphylococcus spp., Salmonella spp. and sulfite-reducing Clostridium spp.) were not detected in the analyzed feeds mixtures. Yeast and mould contamination in 
analyzed feed mixtures was insignificant. The highest was in the feed mixture $\mathrm{K}$ $(30 / \mathrm{g})$, and only $10 / \mathrm{g}$ in feed mixture B and C. The best result was found feed mixture A, where total yeast and mould count was below detection limit.

Table 3. Bacteriological and mycotoxicological safety of feed feed mixtures

\begin{tabular}{|l|c|c|c|c|}
\hline Parameter & $\mathrm{K}$ & $\mathrm{A}$ & $\mathrm{B}$ & $\mathrm{C}$ \\
\hline Total bacteria/g & 39,000 & 2,700 & 5,000 & 2,100 \\
\hline Total yeast and mould count/g & 30 & $<10 / \mathrm{g}$ & 10 & 10 \\
\hline Alternaria alternate & + & + & & + \\
\hline Aspergillus candidus & + & & & + \\
\hline Aspergillus flavus & + & & & + \\
\hline Aspergilus fumigatus & + & & + & + \\
\hline Chrysosporium merdarium & + & & & \\
\hline Fusarium verticillioides & + & & + & \\
\hline Mucor mucedo & + & & + & + \\
\hline Rhizopus nigricans & + & & & + \\
\hline Identified yeast species & 8 & 1 & 3 & 6 \\
\hline
\end{tabular}

The highest number of yeast species (9) was found in the feed mixture K. The predominant were the representatives of the Aspergillus (A. candidus, A. flavus i A. fumigatus) species, a typical mycobiota developed in the animal feed warehouses. Other identified mould species included Alternaria alternata, Fusarium verticillioides, the most common contaminant of corn kernel after harvest and during storage, and Chrysosporium merdarium frequently found in the infested soil and crop debris (Domsh et al., 1980). Number of identified yeast species was significantly lower in the feed mixture A (1) and B (3), i.e. somewhat lower in $C(6)$ in relation to the feed mixture $\mathrm{K}(8)$.

Reduction in total number of microorganisms (bacteria, yeasts and moulds) in the pelleted feed mixtures was reported by Bočarov-Stančić et al. (2009), and in the extruded feeds by Lević and Sredanović (2010). Adamović et al. (2009) reported positive effect of pelleting on the microbiological quality of bentonite supplemented $(1.5 \%)$ calf feed

However, the presence of six analyzed mycotoxins (aflatoxin $\mathrm{B}_{1}$, ochratoxin A, ZEA, DON, DAS and T-2 toxin) was not determined. It is not surprising due to the low fungal contamination of pelleted feed samples, and the absence of potentially toxigenic mould types, with the exception of $A$. flavus and $F$. verticillioides. Although literature data (Lević, 2008) show that the mentioned Fusarium species have potential to synthesize a number of different mycotoxins (bovericin, fumonisins, moniliformin etc.) including fusariotoxins analyzed in this paper (DAS, T-2 toxin, DON and ZEA), it appeared that the requirements for toxin production had not been met.

The obtained results concerning bacteriological and mycotoxicological quality of feedstuffs are likely due to the high adsorption capacity of analyzed 
agents, that is, their capacity to bind excessive moisture rapidly and successfully, thus reducing likelihood of bacteria and mould growth. Obtained results are also indicative of the high quality and hygienically sound initial raw material, as well as the employed feed milling technology.

\section{Conclusion}

Pelleting agent supplementation (Arbocel"- lignocellulose concentratebased and "Bentopel"- bentonite based) in the concentration of $2 \%$, improved pellet hardness, reduced total number of bacteria and number of identified mould species in the feed mixtures . However, following supplementation of both agents in the concentration of $1 \%$, no improvements in pellet hardness and microbiological and mycotoxicological quality of analyzed feed mixture were found.

\section{Acknowledgment}

This research work has been conducted within the project TR 31003 funded by the Ministry of Education and Science of the Republic of Serbia

\section{Uticaj dodataka za peletiranje na mikrobiološku i mikotoksikološku ispravnost krmnih smeša}

M. Adamović, A. Bočarov-Stančić, V. Pantić, M. Vukić-Vranješ, R. Jovanović, M. Panić

\section{Rezime}

Ispitivan je uticaj dodataka za peletiranje na fizičke $i$ hemijske karakteristike, mikrobiološku i mikotoksikološku ispravnost peletiranih krmnih smeša (KS) za koke nosilje. Ispitivane su četiri smeše: kontrolna $(\mathrm{K})$ - bez dodatka za peletiranje, i tri odgledne (A, B i C) sa dodatkom za peletiranje. U smeši A, korišćen je dodatak na bazi koncentrata sirove celuloze -"Arbocel" (2\%), u smešu B na bazi bentonita -"Bentopel" (2\%). U smešu C dodata su oba ispitivana sredstva u količini od po 1\%. Najveća tvrdoća peleta je utvrđena u krmnoj smeši B (6 Khal $\mathrm{J} / \mathrm{kg})$, dok je u smeši A bila neznatno manja (5,5 Khal $\mathrm{J} / \mathrm{kg})$, a najmanja u smeši $\mathrm{C}$ (3,5 Khal J/kg).

Najveći broj ukupnih bakterija utvrđen je u smeši K i iznosio je 39.000/g uzorka, dok je u oglednim smešama bio višestruko manji i kretao se od 2.100 (C) 
do 5.000 (B). Patogene bakterije nisu detektovane ni u jednoj od ispitanih smeša. Najveći broj vrsta plesni (8) utvrđen je u smeši K, dok je u oglednim smešama bio znatno manji. U smeši A utvrđena je 1 vrsta plesni, smeši B tri a u smeši C 6 vrsta. Dominantni su bili predstavnici roda Aspergillus - tipične mikobiote za skladišne uslove čuvanja stočne hrane. Ni u jednoj od ispitivanih smeša nije utvrđeno prisustvo mikotoksina (aflatoksin $\mathrm{B}_{1}$, ohratoksin $\mathrm{A}$, zearalenon, dezoksinivalenol, diacetoksiscirpenol i T-2 toksin).

Dodaci za peletiranje krmnih smeša na bazi koncentrata sirove celuloze i bentonita, u količini od $2 \%$, uticali su na povećanje tvrdoće peleta, smanjenje broja ukupnih bakterija i identifikovanih vrsta plesni. Korišćenje oba ispitivana dodatka, u količini od po $1 \%$, nije uticalo na povećanje tvrdoće peleta i znatnije poboljšanje njihove mikrobiološke i toksikološke ispravnosti.

\section{References}

ADAMOVIĆ M.J., BOČAROV-STANČIĆ A.S., PANTIĆ V.R., RADIVOJEVIĆ M.A., ADAMOVIĆ I.D., STOJANOVIĆ B.D. (2009): Influence of pelleting on microbiological and mycotoxicological correctnes of feed mixtures with bentonite supplement. Zbornik Matice srpske za prirodne nauke, 116 , 113-119.

ASAE (1996): Cubes, pellets and crumbles-definitions and methods for determining density, durability and moisture content. No S 269.4.

BOČAROV-STANČIĆ A., ADAMOVIĆ M., PANTIĆ V., DOLIĆ B., VUKIĆVRANJEŠ M. (2009): Dinamika mikrobiolonjke i mikotoksikološke kontaminacije praškaste i peletirane smeše za telad u uslovima zimskog magacioniranja. 13. Međunarodni simpozijum "Tehnologija hrane za životinje", N. Sad, 29.09.01.10.2009, Zbornik radova, 103-110.

CHUKWUKA O.K., OKOLI I.C., OPARA M.N., OMEDE A.A., OGBEUEWU I.P., IHESHIULOR O.O.M. (2010): The growing problems of mycotoxins in animal feed industry in west Africa. Asian J. Poultry Sci, 4, 122-134.

DOMSH K. H., GAMS W., ANDERSON T.-H. (1980): Compendium of soil fungi. Academic press, London.

ELLISS, M.B. (1971): Dematiaceous Hyphomycetes. Commonwealth Mycological Institute, Kew, Surray, England.

GRUBIĆ G. (1995): Neki fiziološki efekti peletiranje smeše koncentrata u ishrani teladi. Savremena poljoprivreda, 43, 3, 119-123.

ĐORĐEVIĆ N., DINIĆ B. (2007): Hrana za životinje. Cenzone-tech Europe. Aranđelovac.

LEVIĆ J.T. (2008): 5. Mikotoksini i mikotoksikoze. U: Vrste roda Fusarium u oblasti poljoprivrede, veterinarske $i$ humane medicine. Institut za kukuruz "Zemun Polje" i Društvo genetičara Srbije, Cicero, Beograd, 277-430.

LEVIĆ J., SREDANOVIĆ S. (2010): Toplotni tretman u preradi hrane za životinje. 
Tehnologija ekstrudiranja u obradi hrane za životinje i ljude. Tematski zbornik, 122.

PEPELJNJAK S., BABIĆ A. (1991): Detection of trichothecenes mycotoxins, T-2, HT-2, DON and DAS by thin-layer chromatography and biological methods. Prehr.-tehnol. biotehnol. Rev., 29, 65-70.

SAMSON R.A., VAN REENEN-HOEKSTRA E.-S. (1988): Introduction to foodborn fungi. $3^{\text {rd }}$ ed., Centraal Bureau voor Schimmelcultures, Baarn, Delft, Neetherland.

SLUŽBENI LIST SFRJ (1980): Pravilnik o metodama vršenja mikrobioloških analiza i superanaliza životnih namirnica, i Postupak određivanja prisustva, izolacije i identifikacije mikroorganizama, 25, 856-861.

SLUŽBENI LIST SFRJ (1987): Pravilnik o metodama uzimanja uzoraka i metodama fizičkih, hemijskih i mikrobioloških analiza stočne hrane, 15, 422-449. SLUŽBENI GLASNIK R. SRBIJE (2010): Pravilnik o kvalitetu hrane za Životinje, 4, 30-61.

SRETENOVIĆ LJ., GRUBIĆ G., ADAMOVIĆ M., JOVANOVIĆ R., ĐUKIĆ N., SAVIĆEVIĆ R., BOKIĆ N. (1995): Uticaj peletiranje smeša koncentrata na zastupljenost nepoželjnih mikroorganizama i plesni. 7. Kongres mikrobiologa Jugoslavije, Herceg Novi, Zbornik rezimea, 183-184.

STOJANOVIĆ B., GRUBIĆ G., ĐORĐEVIĆ N., ADAMOVIĆ M., RADIVOJEVIĆ M. (2008): Značaj peletiranje i korišćenja natrijum-bentonita u proizvodnji smeša za ishranu goveda. Biotehnologija u stočarstvu, 24, 435-444.

THOMAS M., VAN DER POEL, A.F.B. (1996): Physical quality of pelleted animal feed 1. Criteria for pellet quality. Animala Feed Science Technology, 61, 89-112.

WHITLOW L.W., HAGLER W.M. (2009): Mycotoxins in dairy cattle: occurrence, toxicity, prevention and treatment. North Carolina State University, Raleigh, https://www.msu.edu/ mdr/mycotoxins.pdf 